\title{
Social policy and welfare regimes typologies: Any relevance to South Africa?
}

\author{
Ndangwa $\mathrm{NOYOO}^{1}$ \\ University of Cape Town
}

\begin{abstract}
This paper revisits Esping-Andersen's welfare regimes typology and applies it to the South African context. To argue its case, it refers to and uses the construct of colonialism of a special type. The paper notes that unlike other African countries, Esping-Andersen's framework resonates with South Africa's social policy and welfare regime because of its unique history that partly stems from colonialism of a special type. It argues that social policy in present-day South Africa continues to reproduce colonial and apartheid socio-economic outcomes due to path dependency. The paper asserts that path dependency has largely been shaped by colonialism of a special type. The discussion then concludes that South Africa straddles the liberal and social democratic welfare state regimes and classifies it as a hybrid welfare regime.
\end{abstract}

Keywords: Apartheid, colonialism, colonialism of a special type, path dependency, social policy, welfare regimes

\section{Introduction}

This paper discusses social policy and the notion of welfare regimes typologies in the context of South Africa. It draws heavily on the analyses of Gøsta Esping-Andersen (1990; 1999). In particular, his 1990 seminal book: The Three Worlds of Welfare Capitalism is given special attention in this essay. This book generated wide interest in social policy and social welfare circles, from the 1990s to date. Nevertheless, Esping-Andersen's research was preceded by the work of other social policy and welfare experts, for example, the British academic Richard Titmuss. Titmuss's work had also stirred a lot of discussions in academia and beyond. Titmuss (1974) had identified three models of the welfare state, namely: residual; industrial achievement-performance; and institutional redistributive. Previously, Wilensky and Lebeaux (1958) had identified the residual and institutional welfare systems in industrialised capitalist societies. However, Titmuss had deviated from the former authors' line of thought by emphasising the ideological differences of welfare regimes. He also argued that policy choice and not the level of economic development determined the welfare state regime of a particular country (Titmuss 1963; 1974). Thus, the welfare regime concept is not new. Given the foregoing,

\footnotetext{
${ }^{1}$ Ndangwa Noyoo is Associate professor at the Department of Social Development at the University of Cape Town.
} 
therefore, the objective of this paper is to apply Esping-Andersen's framework to South Africa. In doing so, it tries to explain some of the contradictions inherent in the contemporary social policy and welfare regime of South Africa emanating mainly from path de-pendency. It can be argued that although Esping-Andersen's framework was conceptualised from a Western European standpoint, it could serve as a useful theoretical lens to analyse the social policy and welfare regime of an African country like South Africa. Hence, the re-statement of this theoretical framework relates to its applicability to the South African case and particularly how it can be informed by the idea of colonialism of a special type. Arguably, the phenomenon of colonialism of a special type has been treated peripherally by different social policy and welfare scholars who previously examined South Africa's social policy and welfare regime.

It is important to note that the thesis of colonialism of a special type serves to identify the problem of the bifurcated and class form which welfare has taken in contemporary South Africa as conditioned by colonialism and apartheid. It serves as a pointer to a race-based and class-based welfare regime which is exemplified by a privileged social status of white South Africans through their relationship with the market on the one hand, and a largely poor and unemployed as well as small emergent black middle-class on the other. Black South Africans continue to shoulder the burden of poverty and unemployment in South Africa 23 years after democracy. For instance, blacks constitute the largest proportion of South Africans who are poor. The poverty headcount stands at 55.5\% (StatsSA 2017a). With a high unemployment rate of $27.7 \%$ (StatsSA 2017b), the quality of life of most black South Africans remains appallingly low. Curiously, South Africa's social policy and welfare regime continue to reproduce the socio-economic outcomes of colonialism and apartheid, albeit in muted form. Despite numerous social policy and welfare interventions by the state, which were and are still couched in anti-poverty measures, many South Africans continue to wallow in poverty and are enfeebled by a plethora of social ills. It is noteworthy that the state's responses to poverty and other forms of human deprivation seem to be failing to reduce poverty, unemployment and various social ills in the country. This failure, it can be argued, emanates from politicians', policy-makers' and academics' inability to effectively interrogate the aftermath of colonialism of a special type and then properly located it in contemporary social policy and welfare responses. Arguably, colonialism of a special type fostered path dependency which continues to reproduce and reinforce colonial and apartheid socio-economic out-comes in present-day South Africa.

Path dependency is crucial to the understanding and untangling of South Africa's human deprivation challenges which seem to defy state-led policy interventions and various responses that tried to erase the socio-economic residue of the colonial and apartheid order, since 1994, when South Africa became a democratic country. Therefore, it is important to locate and analyse path dependency in the context of social policy and welfare regimes. According to Trouvé et al. (2010: 4), the path dependency analytical framework is part of the school of thought of the historical institutionalism, which considers institutions as structural variables from which stem arrangements of ideas, interests, and powers. They are the focal point of the activity of public policies, in the sense that institutions contribute to structuring them by encouraging or constraining the organisations and their actors and thus their activities. Path dependency theory starts from the premise that organisations and actors are part of 
institutions that structure and channel their behavioural standards and activities along established paths. Trouvé et al. (2010: 4) further note that these paths are made up of institutions (with their values, standards and rules) and public policies determined by previous choices that impose constraints on institutional development processes. Thus the notion of dependence in relation to the path taken highlights the historical dynamic that dictates that once a path is chosen, it is difficult to change it because the processes become institutionalised and are reinforced over time. Hence, it becomes increasingly difficult to reverse past institutional choices because not following the rules and standards established by previous choices (exit option) generates 'costs' in terms of investment, learning, co-ordination and anticipation. That is why existing institutions are usually modified and not replaced despite their less than optimal nature, and institutional inertia is generated (Trouvé et al. 2010: 4). Since path dependency in South Africa is inextricably linked to colonialism of a special type, according to this discussion, the next section sheds light on this thesis, whilst providing the paper's historical background and context.

\section{Colonialism of a special type and path dependency in South Africa}

The starting point for this paper's line of argument is that South Africa is first and foremost a capitalist society which was inserted into the global capitalist order, several centuries back, by an occupying European settler population. These settlers had tried to supplant the indigenous social security systems and institutions that had responded to the needs of Africans prior to colonial domination. According to Mhone (2001), capitalism emerged in this part of Africa as a racial type of capitalism, which was superimposed over pre-capitalist social relations, entailing unequal relations of domination and subjugation. In this regard, the large European population in South Africa had eventually taken its own form of occupation by diluting ties with the imperial countries and carving out a niche for itself. Colonialism of a special type gave birth to a variant form of capitalism and later welfare capitalism. Arguably, some analysts and theorists tend to gloss over this critical issue when they examine South Africa's social policy and welfare regime. More often than not, they attempt to characterise South Africa as any other post-colonial society. Arguably, there are few research studies that examined welfare capitalism in the context of South Africa against the backdrop of colonialism of a special type. Seekings (2005: 8) rightly notes: "Unfortunately, there is little research on the experiences of 'welfare capitalism' in Southern societies." The question to ask when we are investigating South Africa's social policy and welfare regime is: Why is this country different from the rest of post-colonial Africa? To answer this question and engage with other issues raised in the paper, both historical and political economy approaches will be employed. This stance is taken whilst bearing in mind that the making and implementation of a public policy such as social policy is fundamentally political (Bueno de Mesquita 2016).

Before the democratic elections of 1994, South Africa's social policy and welfare regime were underpinned by the values and ethos of colonialism and apartheid. Given this past, it is worth considering how the country 'won' its freedom. It can be said that in the end, the 
main protagonist against the apartheid state, the African National Congress (ANC), emerged as the sole negotiator for the country's freedom. Thus, the ANC had to engage with the former apartheid political functionaries of the National Party (NP) and begin laying the foundation for a new post-apartheid society. This process inadvertently resulted in the ANC inheriting the colonial-apartheid state-template from the NP which it then used to create a post-apartheid society. In short, power was not wrested from the apartheid rulers, but it was negotiated and then transferred to the ANC, with attached conditions. This arrangement was referred to as the 'sunset clause' and provided for a period of compulsory power-sharing in the form of a Government of National Unity (GNU); an offer not to purge the security forces and civil service of 'counter-revolutionary' elements, and the willingness to establish (during negotiations) a set of Constitutional Principles that could not be violated by the final Constitution (Marais 2001: 87). Thus, the radical transformation of South Africa could not transpire after 1994 because of the 'sunset clause' which not only reinforced path dependency but also cemented the 'Two-Nation' phenomenon. In this sense, the former serves to strengthen the dual nature of the South African economy and welfare system. According to Mbeki (1998: 3) South Africa mirrors the "reality of two nations, underwritten by the perpetuation of the racial, gender and spatial disparities born of a very long period of colonial and apartheid white minority domination..." The aforementioned issues again serve to perpetuate path dependency in relation to social policy and welfare outcomes in South Africa.

The evidence on the above-mentioned duality was illustrated starkly by the United Nations Development Programme (UNDP), in its Human Development Report of 1994 where South Africa had a Human Development Index (HDI) score of 0.650, giving it a mid-pack ranking of 93 out of 174 countries included in that year's report. In the report, the UNDP disaggregated HDI data by race for 14 countries, including South Africa, and revealed dramatic disparities in HDI scores for black and white South Africans. If black South Africa were a country, it would have had an HDI score of 0.462 and a rank of $123^{\text {rd }}$, just above Congo; white South Africa, if it was also a country, would have had an HDI score of 0.878 and a rank of $24^{\text {th }}$, just above Spain (Stacey 2014: 94). Again, this duality cannot be separated from the deep penetration of colonialism in this part of Africa resulting in colonialism of a special type, in stark contrast to other parts of the continent. According to Marais (2001), the definitive origins of South Africa's status as a 'Two Nation' society - marked by the systematic and violent segregation between privilege and deprivation - lie in the nineteenth century, when the development of capitalism accelerated rapidly after the beginning of diamond mining in 1867 and gold mining in 1886:

"These discoveries set in train processes that would definitely shape South African history for the next century. A huge influx of foreign, namely British capital put the mining industry on the world map and spearheaded the highly centralised character of an industry which would remain at the centre of the South African economy for the next century. There was a rush of European immigrant labour, which supplied the semi-skilled and skilled labour, required by the industry and boosted the numbers of white settlers beyond the levels typical in African colonies." (Marais 2001: 8) 
Marais (2001) further reminds us that such developments saw the integration of the 'South African' (since its exclusion was based on race and thus could not be for everyone) society into the world economy as a source of primary commodities (the value of which was set in the European metropoles) and a destination for investment capital. Capital accumulation would be based on the exploitation of a low-wage, highly controlled, expendable African workforce which was to be reproduced in a system of 'native reserves' at minimal cost to capita. This accumulation path seemed to correspond to those of African colonies, with the important distinction that a large settler population, itself segmented culturally and socio-economically, soon became ascendant in the political, administrative and later, economic realms (Marais 2001: 9). Hence, the coinage: colonialism of a special type. The ANC (1987: 1) reports:

"The South African National Liberation Movement, the ANC and its allies, characterise the South African social formation as a system of 'internal colonialism' or 'colonialism of a special type'. What is 'special' or different about the colonial system as it obtains in South Africa is that there is no spatial separation between the colonising power (the white minority state) and the colonised black people. But in every respect, the features of classic colonialism are the hallmark of the relations that obtain between the black majority and white minority. The special features of South Africa's internal colonialism are compounded by the fact that the white South African state, parliament and government are juridically independent of any metropolitan country and have a sovereignty legally vested in them by various Acts of the British government and state." (ANC 1987: 1)

Thus, unlike other African countries where the colonisers externalised the colonies' profits to Europe, the settlers in South Africa used such profits to create similar conditions as those in Europe for themselves. Thus, the settlers invested heavily in the white 'enclaves' where they resided and neglected the areas where the blacks lived which were referred to as 'Homelands' or 'Bantustans'. In the apartheid era, there was a clear link between social policy, welfare programmes and employment as well as access to other life chances such as housing, education and health. The system of institutionalised racism and its overt forms of exclusion, regarding blacks, was constructed in such a way that it influenced employment and the general social structure as Esping-Andersen (1990) argued. Accordingly, the colonial-apartheid welfare regime was characterised by exclusionary patterns of state, market and household forms of social provision, whereby access was defined by the criterion of race. Hence, different races had different welfare programmes, with whites having the best quality of life in apartheid South Africa due to superior services and blacks having the worst because they were politically, socially and economically excluded:

"But the most important factor was the imperative - for the NP - of raising its 'poor white' supporters out of poverty and the attendant risks of becoming sub-ordinate to or intermingling with African people. Old-age pensions constituted one cornerstone of the 'civilised labour' policies by which the Pact Government sought to raise all white people to 'civilised' standards of living, above rather than below or alongside the 'native' (African) population." (Seekings 2007: 378) 
In the apartheid state, the white wage earners were protected in such a way that labour policies were designed to insulate the labour-market position of white workers against societal shocks. The industrial conciliation machinery provided wage protection and thus job reservation was ensured. Notably, the apartheid state resembled a racially exclusive variant of the Australian 'wage earners' welfare state, that is, a welfare state that sought to ensure a certain standard of living for Australians as wage earners than as citizens (Department of Social Development 2002: 26). Black South Africans on the other hand were subjected to extensive labour-market discrimination and disadvantages: inferior education, influx control', the Group Areas Act (which designated where black people and other races could reside) and a host of other instruments which undermined black incomes and other life chances. Given the chronic labour shortages that had plagued low-wage sectors (notably agriculture and mining) during the post-Second World War period, the apartheid state was averse to providing any alternative means of subsistence for African job seekers (Department of Social Development 2002). If we use Esping-Andersen's framework to analyse this scenario, it will show us that the white workers' jobs during apartheid were decommodified to such an extent that even unskilled or unemployable whites were guaranteed jobs just because of their race. In the light of the foregoing, it can be seen that typologies of welfare regimes are context and history specific (this writer's emphasis) (Esping-Andersen 1999).

While the South African white politicians and policy-makers were busy creating a welfare state exclusively for whites during the said period, it is important to bear in mind that Africans were not sitting idly. During the Second World War, the ANC, which had been formed earlier in 1912 to press for African people's civil and political rights, had presented its vision on citizenship and social rights to the Western powers that were leading the war effort against Nazi Germany. In December 1942, the conference of the ANC requested its President, Dr. A.B. Xuma, to appoint a committee to study the Atlantic Charter and draft a bill of rights to be presented to the peace conference at the end of the war. Previously, the Atlantic Charter had been proclaimed on August 14, 1941, by President Franklin D. Roosevelt of the United States and Prime Minister Winston Churchill of Great Britain, as a statement of the peace aims of the Allies (ANC 2013). Accordingly, an Atlantic Charter Committee - consisting of prominent African professionals and intellectuals of varied political views - met on December 13 and 14, 1943, in Bloemfontein. Professor Z.K. Matthews was elected Chairperson. The report of this Committee known as the "Africans' Claims in South Africa" was unanimously adopted by the ANC's annual conference on 16 December 1943. The "Africans' Claims in South Africa" which was essentially a statement of the aspirations of the African people, was one of the most important documents of the ANC. However, when Xuma requested an interview with then Prime Minister, Jan Smuts, to discuss it, he was spurned. Xuma had received a reply that Smuts was "not prepared to discuss proposals which are wildly impracticable" (ANC 2013). What can be drawn from the Africans' Claims document is that it is something that echoed the notion of citizenship and citizenry entitlements that was emerging in Western European welfare states.

It can be argued that the ideas in the Africans' Claims were not diametrically different from those of William Beveridge, the architect of Britain's welfare state, and of T.H. Marshall, a pioneering scholar of social citizenship. Poignantly, these ideas had significantly 
shaped political processes and social welfare discourses in Western Europe. Vincent (2010: 212) sheds some light on this thinking pertaining to citizenship and observes: "In Britain, for example, it can be identified with ideas from the early 1900s around the 'new liberalism', 'liberal socialism', and 'social democratic' thinking, as implied in the work of, for example, L.T. Hobhouse, J.A. Hobson, William Beveridge, J.M. Keynes and Marshall himself." This strand of thought relating to citizenship and social rights would continue to inform the ANC's intellectual position and mechanisms to shape a post-apartheid society. For instance, in 1955, a Congress of the People was convened at Kliptown Township outside Johannesburg to proclaim and adopt the Freedom Charter. This document articulated a vision for a post-apartheid South Africa which arguably was social democratic and socialist in outlook and content:

"All people shall have the right to live where they choose, to be decently housed, and to bring up their families in comfort and security; Unused housing space shall be made available to the people; Rent and prices shall be lowered, food plentiful and no one shall go hungry; A preventive health scheme shall be run by the state; Free medical care and hospitalisation shall be provided for all, with special care for mothers and young children; Slums shall be demolished, and new suburbs built where all have transport, roads lighting, playing fields, crèches and social centres; The aged, orphans, the disabled and the sick shall be cared for by the state; Rest, leisure and recreation shall be the right of all; Fenced locations and ghettoes shall be abolished and laws which break up families shall be repealed." (Congress of the People 1955: 2)

From the foregoing citation, two issues can be established. First, the thinking that undergirded the Freedom Charter was aligned to the welfare state discourse of post-Second World War Western Europe. Indeed, it can be said that some sections of the Freedom Charter resembled Beveridge's plan. However, what is noteworthy about the Freedom Charter's evocations is that the things it envisioned for a new South Africa were already existing in a parallel society, namely, the enclave of white South Africa. While blacks in South Africa did not have decent housing, education and health-care, among other things, white South Africans on the other hand, were well catered for through state, private and voluntary service provision. A second aspect that must be underlined is that a statist led approach to social policy and service provision was advocated by the Freedom Charter. Critically, the Freedom Charter, throughout the liberation struggle, formed an "ideological bedrock and key hegemonic instrument for the ANC. Idealistic and emotively phrased, it bore close resemblance to the French Declaration of the Rights of Man or the Declaration of Independence of the North American colonies" (Marais 2001: 74). Later, as the winds of change were quickly gathering pace in South Africa, the ANC had to prepare for negotiations with the apartheid regime. In 1992, the ANC adopted at its National Conference the document entitled Ready to Govern. This document was the initial blue-print that guided the ANC in the building of a new South Africa just after it was unbanned. The document was structured in such a way as to highlight the strong relationship between the creation of political democracy and social and economic transformation (ANC 1992). Subsequently, in 1994, the Reconstruction and Development Programme (RDP) was adopted by the new 
ANC-led government. Among other things, the RDP portrayed development as a marginal effort of redistribution to areas of urban and rural poverty. In this view, development was taken as a deduction from growth (ANC 1994). Also, it can be argued that the RDP resembled the social democratic tradition of wealth redistribution through high quality social services.

Nevertheless, in line with the economic growth models of the new South Africa, redistribution was not solely pursued at the expense of prudent macro-economic management - as was the case in some post-colonial African states, where emotive and rhetorical positions were adopted in matters of social policy and social welfare. Hirsch (2005) observes that the ANC's approach can be summarised as elements of a Northern European approach to social development combined with elements of Asian approaches to economic growth, within conservative macroeconomic parameters. To this end, the Growth, Employment and Redistribution (GEAR) strategy was adopted in 1996 in furtherance of the postapartheid development goals although many actors on the left were confounded by this policy shift by the government. This was due to the fact that they saw it as heavily steeped in a neo-liberal philosophy and thus it was regarded as anti-poor in orientation. However, the government saw GEAR as a driver of economic growth that would spur social development:

"The higher growth path depends in part on attracting foreign direct investment, but also requires a higher domestic saving effort. Greater industrial competitiveness, a tighter fiscal stance, moderation of wage increases, accelerated public investment, efficient service delivery and a major expansion of private investment are integral aspects of the strategy. An exchange rate policy consistent with improved international competitiveness, responsible monetary policies and targeted industrial incentives characterise the new policy environment." (Department of Finance 1996: 22)

According to Hirsch (2005: 3) the "ANC government followed a consistent economic philosophy that had the following elements: at the centre is a social democratic approach to social reform - it is the state's job to underwrite the improvement in the quality of life of the poor and reduce inequalities, but with a firmly entrenched fear of the risks of personal dependency on the state and of the emergence of entitlement attitudes." The evolution of social policy and the welfare system from the colonial and apartheid eras, through to the democratic transition, was not linear and yet some features from the country's past have been retained in one form or another. Currently, South Africa's social policy and welfare regime is underwritten by the government's anti-poverty thrust which is expressed in various public expenditure endeavours. Such public expenditure drives the social assistance or social grants, public employment generating schemes and what is referred to in South Africa as the 'social wage'. The former classification is in line with that of Gough and Abu Sharkh (2011: 286) who see South Africa as exhibiting a relatively extensive social policy - in both expenditures, and outreach and literacy levels, but with poor health outcomes, due in large part to the human immunodeficiency virus acquired immune deficiency syndrome (HIV-AIDS) pandemic. The strong public expenditure-based social policy and social welfare were inherited from the past. From as early as the 1920s, South Africa built a welfare state that had weak public contributory programmes but strong social assistance programmes, with sub- 
stantial provision through the market, along the broadly 'liberal' lines identified by EspingAndersen, although with many of the labour market interventions emphasised in the Australian case (Seekings/Nattrass 2015).

Nevertheless, another issue that must be taken into consideration is that even though welfare outcomes have improved considerably since 1994, as Seekings and Nattrass (2015) report, the majority of the South Africa's poor population continue to be locked in poverty and experience on a daily basis various ill-fares mainly due to the earlier cited factors namely, colonialism of a special type, path dependency and the 'sunset clause'. This is where this discussion disagrees with the analysis of Seekings and Nattrass (2015) because the two authors do not substantively interrogate the phenomenon of colonialism of a special type and how then path dependency emerges from this phenomenon. They do not delve deeper into the question of the negotiated settlement or 'sunset clause', and how this could have inadvertently helped to cement the 'Two-Nations' character of South Africa that Mbeki (1998) and Marais (2001) refer to. Needless to say, Seekings and Nattrass (2015) rightly observe that the South African welfare system was not changed. But they leave it at that. They fail to interrogate this anomaly and tease out its far-reaching consequences for future social policy interventions in South Africa. Seekings and Nattrass (2015) seem to fall into the familiar trap of other social policy experts and policy-makers, whereby, instead of treating the present levels of deprivation as anomalous (due to the unique history of South Africa earlier alluded to) they take them as 'normal' challenges prevalent in any emerging economy. Due to this oversight, it can be speculated that this is the reason why social policy and other public policies of the post-apartheid era seem to be failing to redress the inherited colonialapartheid socio-economic disparities.

Another crucial issue worth mentioning which seems to be rarely factored into social policy and welfare regime analyses in South Africa is that of indigenous social security systems. Despite the fact that South Africa's social policy and welfare regime evolved out of colonialism and apartheid, as earlier noted in the paper, indigenous social security systems, which existed for centuries before colonial rule, and then alongside the colonial-apartheid welfare regime were not totally wiped out. Thus, they continue to endure to this day, parallel to the post-apartheid welfare regime. What this means is that even though the capitalist mode of production shapes the contemporary economic and social relations in the country, millions of South Africans continue to live under the rule of local chiefs operating in the ambit of customary law. At the root of the chiefs' power is an admixture of ethnicized tradition, inherited authority and clientelism that fits uneasily with the principles of individual rights and democratic processes that underpin the new political system. The severely diminished status of women under traditional authorities is emblematic of this contradiction (Marais 2001: 303). To recapitulate - due to colonialism of a special type - path dependency, the liberation struggle and the 'sunset clause', South Africa is currently sitting with a mixed or hybrid welfare regime that constitutes reformed features of the old colonial-apartheid welfare regime which is tax-based and non-contributory, and means-tested, such as the social assistance and public employment schemes; some class-based entitlements with 'race connotations' which owe their existence to the 'sunset clause' compromises which are contributory or subsidised by the state, and the new social welfare provisions that arose out of the 
contestation of the liberation struggle known as the 'social wage' and developmental social welfare. Table 1 illustrates the various components of the post-apartheid welfare regime.

Table 1: The post-apartheid welfare regime

\begin{tabular}{|c|c|c|c|}
\hline $\begin{array}{l}\text { Non-contributory and } \\
\text { means-tested forms of state } \\
\text { assistance and public em- } \\
\text { ployment schemes }\end{array}$ & $\begin{array}{l}\text { Contributory enti- } \\
\text { tlements and govern- } \\
\text { ment subsidies }\end{array}$ & Social wage & $\begin{array}{l}\text { Developmental social wel- } \\
\text { fare services }\end{array}$ \\
\hline 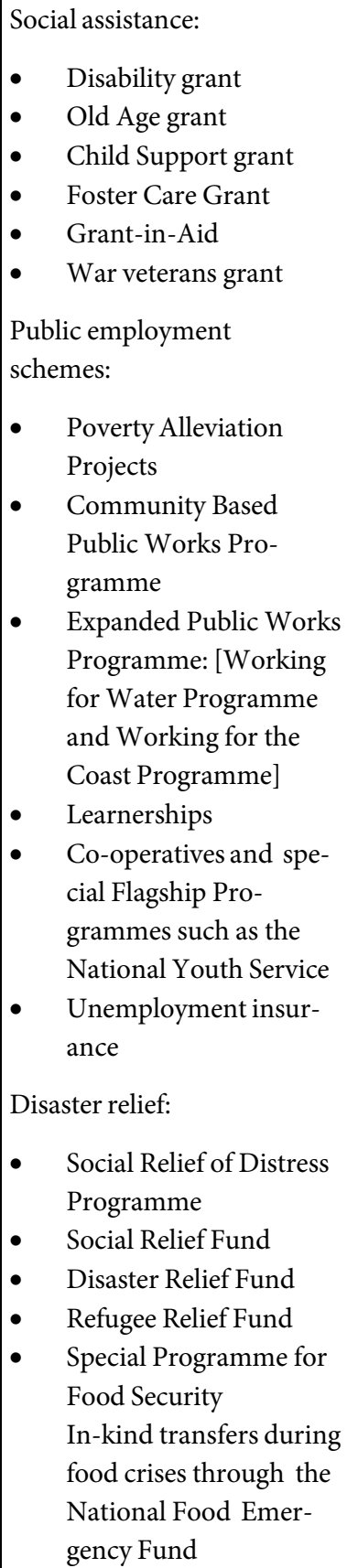 & $\begin{array}{l}\text { Contributory insurance } \\
\text { schemes } \\
\text { Medical-aid schemes } \\
\text { Broad-Based Black Eco- } \\
\text { nomic Empowerment } \\
\text { (BBBEE or B-BBEE) and } \\
\text { Affirmative Action } \\
\text { The National Student Fi- } \\
\text { nancial Aid Scheme } \\
\text { (NSFAS) for tertiary level } \\
\text { students } \\
\text { Tax rebates } \\
\text { Road Accident Fund (RAF) }\end{array}$ & $\begin{array}{l}\text { Basic household security: } \\
\text { Access to necessities: food, } \\
\text { water, housing, electricity, } \\
\text { education, medical care } \\
\text { Consolidated Municipal } \\
\text { Infrastructure Programme } \\
\text { Community Water Supply } \\
\text { and Sanitation } \\
\text { Electricity Basic Support } \\
\text { Services } \\
\text { Tariff Strategy } \\
\text { Integrated Sustainable } \\
\text { Rural Development } \\
\text { Strategy } \\
\text { Rural Infrastructure Strategy } \\
\text { and Free Basic Services Co- } \\
\text { ordination } \\
\text { Free education including } \\
\text { Early Childhood Develop- } \\
\text { ment and free schooling } \\
\text { (targeted at only the poor } \\
\text { and not universal) } \\
\text { Health protection pro- } \\
\text { grammes including Primary } \\
\text { Health Care } \\
\text { Integrated Nutrition Pro- } \\
\text { gramme } \\
\text { National School Nutrition } \\
\text { and Protein Energy Malnu- } \\
\text { trition Scheme } \\
\text { Programme } \\
\text { Prevention of Blind- } \\
\text { ness/Vision 2020 } \\
\text { Trith Care Services }\end{array}$ & $\begin{array}{l}\text { Child protection services } \\
\text { Adoptions services } \\
\text { Services for families in } \\
\text { distress } \\
\text { Services for abused women } \\
\text { Victim empowerment pro- } \\
\text { gramme } \\
\text { Services for the aged } \\
\text { Anti-substance abuse pro- } \\
\text { grammes } \\
\text { Services for orphans and } \\
\text { vulnerable children }\end{array}$ \\
\hline
\end{tabular}

Sources: National Planning Commission 2011; Statistics South Africa 2014 


\section{Re-visiting Esping-Andersen's welfare regime thesis}

Four concepts are at the core of Esping-Andersen's three-fold typology: decommodification, defamiliarisation, social stratification and the state-market nexus (Meuders/O'Dorchai 2007). Esping-Andersen had classified 18 Western European capitalist countries in his 1990 work. He identified three welfare state regimes namely: social democratic as exemplified by Sweden, Norway, Denmark and Finland (since the 1960s); liberal, typified by Britain, Ireland, the United States, Canada, Australia and New Zealand and a conservative or status-based regime, closely linked to Germany, France and Italy. Thus, the term 'regime' refers to the relation between the state and economy. It is a complex of legal and organisational features which are systematically interwoven. Thus, a welfare regime is an institutional matrix of market, state and family forms which generates welfare outcomes. Accordingly, it is these factors that are shaped by different class coalitions working within a context of inherited institutions. EspingAndersen's (1990) work was critiqued by various scholars for its inability to generalise beyond Western Europe. It continues to be appraised and questioned mainly on this basis. For instance, Pinilla-Roncancio (2015) reports that some of the most important critiques were related to the misspecification of states, including the Mediterranean countries, Australia, New Zealand, the UK and Japan. Others focus on his neglect of the gender dimension and methodological critiques associated with the decommodification index. In terms of gender, Lewis (1997: 161) opines that "Esping-Andersen's construction of his 'three worlds of welfare capitalism' is stimulating and thought provoking but like earlier analyses largely ignores women." In this critique, she includes Titmuss as well. Debates pertaining to Esping-Andersen's work are ubiquitous. Powell and Barrientos (2015: 241) conclude that The Three Worlds of Welfare Capitalism has "become one of the most cited works in social policy" (over 20,600 Google Scholar citations as of 20 October 2014).

After a flurry of criticisms related to his 1990 book, Esping-Andersen sought to rectify some of its shortfalls and responded to them in his 1999 book entitled: Social Foundations of Post Industrial Economies. Given the criticisms and other counter arguments related to Esping-Andersen's analysis - especially whether it applied to the South or not - it is quite ironic to note, nonetheless, that he had explicitly stated in his book, that he had not set out to examine all welfare systems in the world. Indeed, Esping-Andersen had clearly stated that he was concerned with those welfare regimes of Western Europe and that his comparative approach was meant to show that welfare states were not all of one type. Furthermore, Esping-Andersen saw the welfare state as the principal institution in the construction of different models of post-war capitalism. In a sense, this approach identifies its subject matter as the 'Keynesian welfare state' or welfare capitalism. To this end, the three regime types he identified are highly diverse with each structured around its own discreet logic of organisation, stratification, and societal integration. Esping-Andersen (1990) noted that these societies, in turn, owed their origins to different historical forces, and that they followed qualitatively different developmental trajectories. Due to this, Esping-Andersen (1990) used a cluster approach in analysing the different European welfare regimes. Thus, Esping-Andersen was more concerned with the 'big picture' which he saw as a trade off to an approach which undertakes a detailed treatment of individual countries or dwells on 
detailed characteristics of the various social programmes - since this was a large-scale comparison in the first place.

One of the main concepts in the work of Esping-Andersen (1990: 22) is decommodification. He observed that in pre-capitalist societies, "few workers were properly commodities in the sense that their survival was contingent upon the sale of their labour power. It is as markets become universal and hegemonic that the welfare of individuals comes to depend entirely on the cash nexus." He argued further that it is exactly this reason that employers have always opposed decommodification. This is because decommodification strengthens the workers and weakens the authority of the employer. He observed that stripping society of the institutional layers that guaranteed social reproduction outside the labour contract meant that people were commodified. Due to this, the introduction of modern social rights implies a loosening of the pure commodity. Esping-Andersen (1990) noted that decommodification occurred when a service was rendered as a matter of right, and when a person maintained a livelihood without reliance on the market. He further observed that decommodification rights were differentially developed in contemporary welfare states. In social assistance dominated welfare states, rights were not so much attached to work performance as to demonstrable need:

"The mere presence of social assistance or insurance may not necessarily bring about significant decommodification if they do not substantially emancipate individuals from market dependence. Means-tested poor relief will possibly offer a safety net of last resort. But if benefits are low and associated with stigma, the relief system will compel all but the most desperate to participate in the market." (Esping-Andersen 1990: 22)

Another central theoretical argument of his work hinged on the idea of social stratification. Esping-Andersen saw social stratification as heavily influenced by institutions, the welfare state, in particular. If this is true, he noted, then cross-national stratification patterns should systematically differ according to the nature of welfare states (Esping-Andersen 1993). $\mathrm{He}$ also asserted that different patterns of social stratification were historically the midwives of different welfare state conceptions (Esping-Andersen 2015). Esping-Andersen (1990) had argued that social policy in conservative welfare regimes had a primary goal of preserving traditional status differences in society. Faced with the potential for instability introduced by the emergence of modern capitalism - which simultaneously produced class dualisms while eroding traditional occupational hierarchies - social policy becomes a way to reinforce a 'natural' social order. Thus, while conservative welfare regimes have historically been associated with significant levels of social expenditure, the contents of social policy may reinforce an existing order. Such conservative welfare states have been associated historically with a strong state, a significant role for religion in society, and an 'old-style' corporatist economic order (Scruggs/Allan 2006: 4). On the other hand, classical liberals reasoned that traditional social patterns constrain individual freedoms, and that free market afforded individuals the ability to realise their potential without the fetters imposed by pre-existing social hierarchies of church and state alike. Lastly, the social democrats, like their conservative and liberal counterparts, 'socialist reformism' was always pursued with distinct stratification outcomes in mind. For labour movements, it was the construction of solidari- 
ty that mattered. Working class unity was a primary desire, although this in itself necessitated broad strategies to overcome issues and policies that divided the class (Scruggs/Allan 2006).

In addition, it is important to bear in mind that the welfare-state construct was central to Esping-Andersen's (1990) work for several reasons:

i. As it was commonly used, the concept of the welfare state was too narrowly associated with the conventional social-amelioration policies.

ii. Contemporary advanced countries clustered not only in terms of how their traditional social welfare policies were constructed, but also in terms of how they influenced employment and the general social structure (Esping-Andersen 1990).

To reiterate, to talk of 'regimes' is to consider the relation between the state and economy, and to be also mindful of a complex of legal and organisational features that are systematically interwoven, according to Esping-Andersen (1990). This thinking also highlights the issue of social rights - as the extension of the former has always been regarded as the essence of social policy. However, Esping-Andersen chose to view social rights in terms of their capacity for decommodification as the outstanding criterion for social rights must be the degree to which they permit people to make their living standards independent of pure market forces. Therefore, social rights diminish citizens' status as commodities. In regard to South Africa, Seekings and Nattrass (2015) argue that post-apartheid South Africa, despite being branded by some critics as 'neo-liberal', expanded the inherited welfare state between 1994 and 2014 which helped to reduce poverty. The country redistributed a larger share of the Growth Domestic Product (GDP) through tax-funded social assistance programmes than almost any other country in the global South. These authors further point out that decommodification was not only extensive, but became increasingly so in the post-apartheid era. The issues raised by the former authors are crucial as they point to the ever-increasing number of citizens on the country's social assistance programme despite some critics alleging that South Africa's welfare regime is 'neo-liberal'. Indeed, these issues are crucial because in a population of 56 million people there are close to 17 million people in receipt of social grants in South Africa, whilst the pool of employed people who can pay taxes to fund this programme continues to shrink. According to the Institute of Race Relations (IRR) (2017), in 2016, there were 15,545,000 people with jobs in South Africa while 17,094,331 people were receiving social grants.

This foregoing skewed picture emanates from the exponential growth in the number of social grants beneficiaries over the years. For example, in 2001 there were 12,494,000 people in employment and 3,993,133 people receiving social grants. By 2016, however, the number of people receiving grants had increased by $328 \%$ while those with jobs increased by only $24 \%$ (IRR 2017). This does not augur well for the country's development prospects as social assistance is a tax-based benefit. With such high levels of unemployment and general joblessness in South Africa, citizenry entitlements may be seriously threatened if the situation does not improve. Thus, based on the foregoing analysis, it can be deduced that South Africa has a hybrid welfare regime typology. This welfare regime continues to reproduce social outcomes befitting the mix of typologies located in the workings of South Afri- 
ca's colonialism of a special type. This hybrid regime partially resonates with the three worlds of welfare capitalism and seems to straddle the Scandinavian redistributive model as attested by the country's provision of bundles of services like the 'social wage' that is defined by various state subsidies like free water, free electricity, free housing and so forth, and universal access to certain services by the poor; and the Anglo-Saxon liberal welfare regime which is exemplified by targeting of services to the mostly poor sections of the country and makes use of the means-tests. The liberal welfare regime evolved out of colonialism and apartheid, and had catered to the needs of whites in South Africa while the social democratic tradition grew out of the liberation struggle. Nonetheless, social stratification in South Africa disqualifies the country from being a fully-fledged social democratic welfare regime because of its high levels of income inequality. For instance, even though the Gini coefficient improved from 0.72 (reported in 2006) to 0.68 in 2015, black Africans still experience the highest income inequality with a Gini coefficient of 0.65 (reported in 2015), up from 0.64 reported in 2006. Income inequality among the white population declined from 0.56 (reported in 2006) to 0.51 in 2015 (The South African 2017).

\section{Conclusion}

This paper argued that South Africa's social policy and welfare regime can be analysed using Esping-Andersen's theoretical framework. It also noted that it is a useful comparative tool that can help people to understand South Africa's social policy trajectory as well as its welfare outcomes in different historical epochs. Esping-Andersen's framework is something that is useful and not redundant as some scholars have suggested. For example, Patel (2009: 16) argues that "there is a general consensus among South African researchers that South Africa's welfare system does not fit neatly into Esping-Andersen's conservative, liberal and social democratic welfare state regimes." For this paper, this is the crux of the matter because Esping-Andersen had not set out to examine South Africa's welfare regime or any welfare regime from the South, for that matter. Be that as it may, the key point that this paper wanted to bring to the fore, is that even though Esping-Andersen's framework may be regarded as limited, it can enable one, for instance, to unpack the duality of the South African society, which was highlighted earlier. This paper had followed a historical and political economy approach. It had also adopted a regime approach and thus placed its discussions within the historical-institutional school of social research (Gough 2013). It did this because it was using Esping-Andersen's regime approach in examining South Africa's social policy trajectory and welfare state regime from the colonial-apartheid era to the present time. This paradigm of thinking about social policy was adopted for three reasons. First, it situates modern welfare states within a wider welfare mix: governments interact with markets and families to produce and distribute welfare. Second, it pays attention to welfare outcomes, the final impact on human security, need satisfaction and well-being. Third, it is a political economy approach which embeds welfare institutions in the deep structures of social reproduction: it forces researchers to analyse social policy not merely in technical but in power terms (Abu Sharkh/Gough 2009: 2). 


\section{References}

Abu Sharkh, Miriam and Gough, Ian (2009). Global welfare regimes: A cluster analysis. Stanford: Centre for Democracy, Development and The Rule of Law.

African National Congress (ANC) (1987). Apartheid South Africa: Colonialism of a Special Type. Accessed on 27.02.2017 at http://www.anc.org.za/content/apartheid-south-africa-colonialismspecial-type

African National Congress (ANC) (1992). Ready to Govern: ANC policy guidelines for a democratic South Africa. Accessed on 27.02.2017 at http://www.anc.org.za/docs/pol/1992/readyto.html

African National Congress (ANC) (1994). Reconstruction and Development Programme. Johannesburg: Umanyo.

African National Congress (ANC) (2013). Africans' Claims in South Africa. Accessed on 27.02.2017 at http://anc.org.za/show.php?id=4474

Bueno de Mesquita, Ethan (2016). Political Economy for Public Policy. Princeton, NJ: Princeton University Press.

Congress of the People (1955). The Freedom Charter: Adopted at the Congress of the People at Kliptown, Johannesburg, on June 25 and 26, 1955. Jeppe: Pacific Press (Pty).

Department of Finance (1996). Growth, Employment and Redistribution: a Macroeconomic Strategy. Pretoria: Department of Finance.

Department of Social Development (DSD) (2002). Committee of Inquiry into a Comprehensive Social Security System for South Africa, 2002. Transforming the Present - Protecting the Future. Pretoria: DSD.

Esping-Andersen, Gøsta (1990). The Three Worlds of Welfare Capitalism. Princeton, NJ: Princeton University Press.

Esping-Andersen, Gøsta (1993). Introduction. In: Gøsta, Esping-Andersen (ed.) Changing Classes: Stratification and Mobility in Post-Industrial Society (1-6). London: SAGE Publications.

Esping-Andersen, Gøsta (1999). Social Foundations of Post Industrial Economies. Oxford: Oxford University Press.

Esping-Andersen, Gøsta (2015). Welfare regimes and social stratification. Journal of European Social Policy, 25(1), 124-134.

Gough, Ian (2013). Social policy regimes in the developing world. In: Patricia Kennett (ed.) A Handbook of comparative social policy (205-224). Cheltenham: Edward Elgar Publishing Ltd.

Gough, Ian and Abu Sharkh, Miriam (2011). Financing welfare regimes: mapping heterogeneous revenue structures. International Journal of Social Welfare, 20, 241-245.

Hirsch, Alan (2005). Season of Hope: Economic Reform under Mandela and Mbeki. Scottsville: University of KwaZulu-Natal Press.

Institute of Race Relations (IRR). (2017). More South Africans receive grants than have jobs - a recipe for chaos and violence. Accessed on 27.10.2017 at file://C:/Users/01458109/Downloads/IRR\%20Press\%20Release\%202013\%20More\%20S outh\%20Africans\%20receive\%20grants\%20than\%20have\%20jobs\%202013\%20a\%20recip e\%20for\%20chaos\%20and\%20violence\%20\%202013\%2021\%20June\%202017.pdf

Lewis, Jane (1997). Gender and Welfare Regimes: Further Thoughts. Social Politics, 4(2), 160-177. 
Mbeki, Thabo (1998). Statement of the Deputy President at the opening of the debate in the National Assembly, on "Reconciliation and Nation Building", Cape Town, 29 May. Accessed on 09.05.2016 at http://www.sahistory.org.za/archive/statement-deputy-president-thabo-mbekiopening-debate-national-assembly-reconciliation-and-n

Meuders, Danièle and O'Dorchai, Sile (2007). The position of mothers in a comparative welfare perspective. In: Daniela Del Boca and Cécile Wetzels (eds). Social Policies, Labour Markets and Motherhood: A Comparative Analysis of European Countries. (1-27). Cambridge: Cambridge University Press.

Mhone, Guy (2001). Labour Market Discrimination and its Aftermath in Southern Africa. Paper prepared for the United Nations Research Institute for Social Development (UNRISD) Conference on Racism and Public Policy, Durban, South Africa.

National Planning Commission (2011). National Development Plan: Vision for 2030. Pretoria: National Planning Commission.

Patel, Leila (2009). Thematic Paper: The gendered character of social care in the non-profit sector in South Africa. Johannesburg: Centre for Social Development in Africa (CSDA).

Pinilla-Roncancio, Monica (2015). Some useful sources. Social Policy \& Society, 14(2), 323-327

Powell, Martin and Barrientos, Armando (2015). Introduction: Twenty-Five Years of the Welfare Modelling Business. Social Policy \& Society, 14(2), 241-245.

Scruggs, Lyle A., and Allan, James P. (2006). Social Stratification and Welfare Regimes for the $21^{\text {st }}$ Century: Revisiting the "Three Worlds of Welfare Capitalism". Accessed on 27.10.2017 at http://councilforeuropeanstudies.org/files/Papers/ScruggsAllan.pdf

Seekings, Jeremy (2005). Prospects for Basic Income in developing countries: A comparative analysis of welfare regimes in the South. Cape Town: Centre for Social Science Research (CSSR).

Seekings, Jeremy (2007). Not a single white person should be allowed to go under: Swartgeever and the origins of South Africa's welfare state, 1924-1929. Journal of African History, 48(3), 375394. 